\title{
Gender Stereotypes And Self-Perceptions Among College Students
}

\author{
Kevin C. Bosner, Medaille College, USA
}

\begin{abstract}
In spite of advances made, women in general still do not achieve the same earnings or positions as men do in corporate America. Gender stereotyping has been identified as a major hurdle for women both in business and on college campuses. This study explores gender stereotypes and selfperception of 338 students enrolled in undergraduate business courses at two Western New York colleges. Using a variation of the Schein Descriptive Index, attitudes about self, same sex and the typical man and woman are compared in terms of positive personality traits of successful managers. It is hoped that such research will help students recognize their own and others' stereotypes, which is considered an important first step in managing them.
\end{abstract}

\section{BACKGROUND}

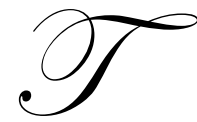

he question of gender stereotyping might not date quite back to the story of Adam and Eve, but it certainly has produced significant debate and dialogue over the ensuing centuries, continuing to the present day. Virtually all American corporations publicly repudiate the concept of discrimination of any kind (Williams, 2005), yet statistical and anecdotal evidence still indicates the presence of both subtle and blatant stereotyping of women into subordinate and supporting roles, with senior management positions being still reserved almost exclusively for men (Ragins, Townsend \& Mattia, 1998).

In order to reduce this imbalance, it is important to look at the origins of gender stereotyping, particularly at the point where such stereotypes begin to merge with beliefs and opinions about ideal qualities for success in corporate management. In the United States, that merging takes place primarily during the college years. By the time young adults enter college, they have developed beliefs about themselves, their career goals, and the value and attributes of people around them (Ridgeway, 2001). These beliefs influence how students interpret the new knowledge they acquire in the academic process, eventually affecting the decisions they will make as managers, including hiring, promotion and compensation choices. This study looked at perceptions of college students about traits of successful managers in an attempt to identify similarities and differences in the responses of the men and women surveyed.

Historically, the division of labor between the sexes was an outgrowth of the most common physical attributes of each (Hofstede, 1983). According to researchers such as Brown (2002), the woman's biological role as a child bearer led her, in many societies, into a nurturer and caregiver role, while the man developed into the role of provider, in large part because he could hunt and move about more freely without the constraints of menstruation, pregnancy or nursing. The woman's skills were valued for maintaining and improving the home, and also to growing food for the times when hunting did not bring in enough (Dubeck \& Dunn, 2006).

As centuries passed and civilizations grew, some of these gender-specific limitations have become less and less relevant, and yet remain the basis for stereotypes in many cultures about the "proper" roles of men and women. Studies by Hofstede (1983) established a masculinity index that measures the extent to which cultures "try to minimize or to maximize the social sex role division" (p. 84). Hofstede's research in the 1960's and 70's also found that cultures with more of such role division always place the male into the more dominant role and the female into the caregiver position. Hofstede classified the United States as moderately masculine. Research sponsored by the Federal Government discovered that such role divisions have become exacerbated in the last half century or so with 
the increasing shift of many economies from industrial to technological, where men receive favorable employment treatment, due to still-prevalent stereotypes about their greater math and science abilities (Tai \& Simms, 2005, and Kasi \& Dugger, 2000).

In North America, and specifically in the United States, women have been joining both the workforce and the ranks of higher education in greater and greater number. (United States Department of Labor (DOL), 2006). But as these women continued their careers, many began to feel stymied and trapped at a certain level by the gender stereotypes and assumptions of a predominantly male managerial population, a phenomenon described as the "glass ceiling" (Morrison, White and Van Velsor, 1987). Morrison et al. defined the glass ceiling as

a transparent barrier, that kept women from rising above a certain level in corporations... the glass ceiling is not simply a barrier for an individual... <it> applies to women as a group who are kept from advancing higher because they are women (p. 13).

Women have made strides in achieving entry into jobs once denied them, and their pay has increased from what it once was. A disparity still exists, however, between men and women in the workplace. The gap in representation and compensation begins as early as one year after college graduation (Dey \& Hill, 2007) and becomes wider the higher in the organization one looks (DOL, 2006).

Stereotyping by both men and women adds fuel to the fire of the controversy about women's employment opportunities. Stereotyping by its nature is difficult to overcome, as human nature has been shown to consistently interpret facts and experiences in ways that reinforce their already existing views (Jackson, Hodge \& Ingram, 1994). Moreover, people tend to ignore experiences which challenge their stereotypes, often by classifying them as exceptions or anomalies rather than accepting a new view of reality. Finally, research has shown that stereotypes begin at an early age and are reinforced through childhood and adolescence (Sargent, 1981). Thus it makes sense to consider stereotypes and gender bias in people not only in the workforce, but before they enter the workforce. For that reason, many researchers, including Brenner (1982), Finlay (2003), Probert (2005), Schein et al. (1989), and Yim \& Bond (2002) have studied gender bias, self-perception and stereotyping on college campuses and classrooms.

\section{Gender Stereotyping Among College Students}

In the past thirty years, several quantitative studies of gender role stereotypes among college students have followed the example of Schein (1973), who defined stereotyping in the context of males' and females' perceptions about traits of successful managers. The Schein Descriptive Index (1973) is a 92-item instrument designed to measure the respondents' stereotypes. It has been used extensively by Schein herself as well as other researchers. In surveys of both male (Schein, 1973) and female (Schein, 1975) middle managers, respondents of both sexes defined managerial traits using terms more typically associated with males than with females. By the late 1980's (Brenner, Tomkiewicz \& Schein, 1989) female managers no longer demonstrated these stereotypes to the same degree, but male managers still did.

Schein and others performed numerous similar studies with college students as the respondents, and found similar results. Schein, Mueller and Jacobsen (1989) reported that in a sample of 228 college students, the males, but not females, used "typically" male terms to describe successful managers. Female students tended to view management jobs as more gender-neutral. Dubno (1985) found that male MBA students had more of a tendency to view female managers negatively, while the female students surveyed regarded female managers in a more positive light. Norris \& Wylie (1995) found the same patterns repeated among Canadian and U.S. undergraduate students.

\section{Purpose Of The Study}

The purpose of this study was to explore for gender stereotyping among college students enrolled in business courses by examining beliefs and perceptions regarding the attributes that are important for success as a manager. Since self-perception has been shown to relate closely to gender stereotyping (Schein, 1975, Yim \& Bond, 
2002), the same students' self-perception of attributes that are important for success as a manager was also measured.

\section{Research Questions And Hypotheses}

There were two general research questions. The first question was: To what degree do college students display gender stereotyping when describing attributes of their own and the opposite gender, relative to their perceptions of characteristics of successful managers?

The second question was: What is the relationship between college students' self-ratings and the ratings they give typical males and typical females, in terms of characteristics of successful managers?

The two questions were converted into four hypotheses:

H1: Undergraduate students in business classes will rate themselves higher than they rate the typical member of their own gender when ranking specific positive personality characteristics associated with successful managers.

H2: Undergraduate students in business classes will rate themselves higher than they rate the typical member of the opposite gender when ranking specific positive personality characteristics associated with successful managers.

H3: As a group, male students will rate themselves no differently on specific positive personality characteristics associated with successful managers than female students rate themselves.

H4: As a group, both male and female students will rate themselves higher on specific positive personality characteristics associated with successful managers than members of the opposite gender rate them.

\section{METHODOLOGY}

A one-time survey was the method of data collection. The sampling frame was undergraduate college students taking business classes at two institutions in the Rochester, New York area. This group was chosen for two reasons. First, business class enrollees are the ones most likely to have career aspirations to business management. At the same time, by broadening the sample beyond business majors exclusively, a more diverse group of students was obtained than if the sample had been limited to business majors only.

One school is private and religious-based; the other is public, a part of the New York State University system. Institution 1 is a private liberal arts college. There are approximately 2,400 undergraduate students enrolled, $58 \%$ of whom are women. Institution 2.is part of the public New York State University system (SUNY). There are now nearly 7,000 undergraduate students, $57 \%$ of them women.

Approximately 800 students were enrolled in business courses at each of the two schools in the most recent academic year. At least half of those students were enrolled in at least two business classes, so a conservative estimate of the survey population is approximately 1200. Surveys were collected from 365 students. After discarding 27 unusable surveys there were 338 usable surveys included in the analysis, providing a confidence level of $95 \%$ with a $5 \%$ margin of error.

\section{Data Collection Instrument And Tool Development}

This study used the Student Skills Perception Survey (SSPS), adapted by the researcher primarily using the Schein Descriptive Index (SDI) and the Sino-American Personal Perceptions Survey (SAPPS). There are eight personality categories or characteristics listed on the SSPS survey instrument: Open to Experience; Emotionally Stable; Outgoing; Hardworking; Intelligent; Helpful; Reserved; and Assertive. These are the same eight constructs used in the SAPPS, adjusted in terminology somewhat for American students with input from Schein. These same construct terminologies also appear on either the Bem Sex Role Inventory (Bem, 1993) and/or the Schein Descriptive Index (Schein, 1973). These construct related characteristics are also found in the Big-Five model of 
personality traits (Barrick \& Mount, 1991). The direct adaptation of the construct terminology of the SSPS from these existing tools with proven reliability and validity supports the construct validity of the SSPS tool.

\section{Data Collection}

The data collection took place during a 10-day period in April 2007. Surveys were distributed to students in the classroom, and the students were given a brief explanation of each of the terms. Instructions were printed on the surveys and also reviewed verbally. The voluntary nature of participation was emphasized.

As the surveys were completed, they were collected by a research assistant. At the conclusion of the data collection period, the research assistant entered all of the data into an Excel spreadsheet. A random sample of 20\% of the coded data from each group of surveys was rechecked against the paper form for accuracy and no keying or entry errors were found.

\section{Data Analysis}

$\mathrm{T}$ tests were performed on total scores as well as on scores for individual factors. The dependent variables analyzed were: Mean Self Score (SELF); Mean Score given to the Typical Member of the Same Sex (SAME); Mean Score given to the Typical Member of the Opposite Sex (OPP); and Mean Score for Successful Manager (MGR).

Of the 365 surveys collected from students, twenty-seven surveys had to be discarded due to illegibility, incomplete answers, or invalid entries, leaving 338 usable surveys which were included in the analysis. Of this sample, $187(55 \%)$ were male and 151 (45\%) female. 189 respondents $(56 \%)$ were from one school and $149(54 \%)$ from the other. So the sample was roughly evenly divided both in terms of gender and school attended. Participants ranged in age from 18 to 49 years old, with a mean age of 21 and a median age of 20.313 of the respondents (93\%) were 25 years old or younger. Gender demographics are displayed in Table 1.

Table 1. Surveys by School and by Gender

\begin{tabular}{cccc} 
& & & Total \\
\hline & Male & Female & $189(56 \%)$ \\
Institution 1 & $111(58 \%)$ & $78(42 \%)$ & $149(54 \%)$ \\
Institution 2 & $76(51 \%)$ & $73(49 \%)$ & \\
\hline
\end{tabular}

\section{Findings Of Hypothesis Testing}

To test for significant differences between the means of two samples, t-tests were performed using SPSS software. The $\mathrm{p}$-value was used with significance level defined as $\mathrm{p}<.05$. Levene's Test for equality of variances was used, along with a 95\% confidence interval. The variables analyzed were: Mean Self Score (SELF); Mean Score given to the Typical Member of the Same Sex (SAME); Mean Score given to the Typical Member of the Opposite Sex (OPP); and Mean Score for Successful Manager (MGR). To further analyze the data, t-tests were also applied to the male and female samples separately.

Hypothesis 1 stated:

Undergraduate students in business classes will rate themselves higher than they rate the typical member of their own gender when ranking specific positive personality characteristics associated with successful managers.

Since the hypothesis specified not only a difference but the direction of that difference, a one-tailed T-test was the most appropriate. An average self score (SELF) was calculated for each participant. Additionally, an average score was calculated for each participant's view of the typical member of the respondent's own gender (SAME). The mean of SELF was 3.924, while the mean of SAME was 3.567. Then a paired samples T-test was used to compare the two. The paired sample test was chosen because for this hypothesis, both measures came from 
the same subjects. Using a 95\% confidence interval, a statistically significant difference was found: $t=14.76, d f=337$, $p=.000$. Testing the male and female respondents separately also yielded significant differences $(t(186)=9.95$, $p<.001$ for male respondents and $t(150)=6.20, p<.001$ for female respondents). The results are summarized in Table 2.

Responses were also counted to determine how many participants' SELF exceeded their SAME. For 144 of the 187 males (77\%) the SELF score was higher than the score given for the "typical man." 106 of the 151 women (70\%) scored themselves higher than they scored the "typical woman." In total, 250 of the 338 respondents (74\%) scored themselves higher than they rated the typical member of their own gender. Thus, Hypothesis 1 is rejected in its null form, the data supporting the alternative hypothesis:

Undergraduate students in business classes will rate themselves higher than they rate the typical member of their own gender when ranking specific positive personality characteristics associated with successful managers.

Table 2. Comparing Mean of Self Scores to Mean View of Own Sex

\begin{tabular}{cccccc}
\hline Gender of Respondent & Score given to Self & $\begin{array}{c}\text { Score given to Typical } \\
\text { Member of Same Sex }\end{array}$ & $\boldsymbol{T}$ & $\boldsymbol{d}$ & $\boldsymbol{p}<\mathbf{0 . 0 1}$ \\
\hline Male (187) & 3.94 & 3.51 & 9.95 & 186 & Yes \\
Female (151) & 3.91 & 3.64 & 6.20 & 150 & Yes \\
All (338) & 3.92 & 3.57 & 14.76 & 337 & Yes \\
\hline
\end{tabular}

Hypothesis 2 stated:

Undergraduate students in business classes will rate themselves higher than they rate the typical member of the opposite gender when ranking specific positive personality characteristics associated with successful managers.

The phrasing is very similar to that of $\mathrm{H} 1$, and testing was done in the same way.

The mean average selfscore (SELF) was compared to the mean average score for the typical member of the opposite sex (OPP). The mean SELF score was 3.92 and the mean OPP score was 3.52. A paired samples t test showed significant differences between the two measures: $t=14.21, d f=337, p=.000$. Testing the male and female respondents separately again yielded significant differences $(t=11.24$ for male respondents and $t=6.13$ for female respondents). for all respondents $(t=12.44)$, as well as males $(t=11.24)$ and females $(t=6.13)$ calculated separately. Table 3 shows the results.

Responses were also counted to determine how many participants' SELF exceeded their OPP. In total, 256 (76\%) of all 338 respondents scored themselves higher than they scored the typical member of the opposite sex. For men, that percentage was $81 \%$, or 152 of the 187 male respondents; for women, the percentage was $69 \%$, or 104 of the 151 female respondents. The data rejects the null hypothesis for $\mathrm{H} 2$ and shows support for Hypothesis Two in its alternate form:

Undergraduate students in business classes will rate themselves higher than they rate the typical member of the opposite gender when ranking specific positive personality characteristics associated with successful managers.

Table 3. Comparing Mean of Self Scores to Mean View of Opposite Sex

\begin{tabular}{|c|c|c|c|c|c|}
\hline $\begin{array}{c}\text { Gender of } \\
\text { Respondent }\end{array}$ & Score given to Self & $\begin{array}{c}\text { Score given to Typical } \\
\text { Member of Opposite Sex }\end{array}$ & $t$ & $d f$ & $p<.001$ \\
\hline Male (187) & 3.94 & 3.52 & 14.21 & 186 & Yes \\
\hline Female (151) & 3.91 & 3.61 & 6.13 & 150 & Yes \\
\hline All (338) & 3.92 & 3.52 & 12.44 & 337 & Yes \\
\hline
\end{tabular}


Hypothesis 3 stated:

As a group, male students will rate themselves no differently on specific positive personality characteristics associated with successful managers than female students rate themselves.

Men's SELF (self scores) were compared to those of women. An independent sample, two-tailed t test was chosen for this test, because no directional difference was proposed, and because the scores came from two different groups, male and female. No statistically significant difference was found in the overall scores $(t=0.751, d f=336$, $p=.453$. $)$. The overall mean for men's self scores $(\mathrm{m}=3.94, \mathrm{sd}=.41)$ was not significantly different from that of the women $(\mathrm{m}=3.91, \mathrm{sd}=.36)$. Further analysis was done to compare male and female self-scores on each of the eight attributes. The results of those tests are shown in Table 4. The mean and standard deviations for men and women are shown for each of the eight categories' SELF scores. The table also shows the results of two-tailed, independent sample t-tests on each category.

Table 4. Comparison of Male Self-Scores to Female Self-Scores

\begin{tabular}{|c|c|c|c|c|}
\hline & $\begin{array}{c}\text { Male SELF } \\
M(S D d)\end{array}$ & $\begin{array}{c}\text { Female SELF } \\
M(S D d)\end{array}$ & $\begin{array}{c}\text { T Score } \\
(d f=336)\end{array}$ & $p$ \\
\hline Assertive & $3.79(.813)$ & $3.65(.826)$ & 1.59 & .113 \\
\hline Emotionally Stable & $4.21(.774)$ & $3.91(.730)$ & 3.63 & .000 \\
\hline Hardworking & $4.23(.820)$ & $4.38(.700)$ & -1.75 & .080 \\
\hline Helpful & $4.12(.716)$ & $4,28(.694)$ & -2.08 & .039 \\
\hline Intelligent & $4.14(.697)$ & $4.04(.662)$ & 1.33 & .184 \\
\hline Open to New Experiences & $4.03(.832)$ & $4.01(.770)$ & 0.23 & .820 \\
\hline Outgoing & $3.87(.913)$ & $3.90(.847)$ & -0.30 & .764 \\
\hline Reserved & $3.12(.896)$ & $3.09(.824)$ & 0,33 & .739 \\
\hline OVERALL & $3.94(.412)$ & $3.91(.361)$ & 0.75 & .453 \\
\hline
\end{tabular}

For six of the eight attributes, as well as for the overall self-rating, there was no significant difference in how men and women scored themselves. For emotional stability, men rated themselves significantly higher than did women ( $t=3.63, p=.000)$ while women's self-scores for helpfulness were significantly higher than men's $(t=2.08$, $p=.039)$. Since the overall means, as well as the means of six of the eight self scores, were not significantly different between men and women, Hypothesis Three is supported.

Hypothesis four stated: As a group, both male and female students will rate themselves higher on specific positive personality characteristics associated with successful managers than members of the opposite gender rate them. In other words, this hypothesis tests whether males and females differ significantly in their view of the "typical" man and woman.

Women's SAME scores were combined with men's OPP scores to obtain ratings for the "typical woman." Similarly, to rate the "typical man," men's SAME scores were combined with women's OPP scores. Then, onetailed, independent sample T-tests were performed on each of the eight categories, and the overall rating, comparing the views of the two genders. The one-tailed test was used since the alternative hypothesis suggested a directional difference.

Women gave the typical man higher ratings than men themselves did on six of the eight categories Assertive, Emotionally Stable, Hardworking, Intelligent, Open to experience, and Outgoing - as well as overall. The 
only categories where men rated the typical male higher than women did were Helpful and Reserved. Four of the eight differences - Emotionally Stable, Open to experience, Outgoing, and Reserved - were significant. The difference in overall rating $(t(336)=-2.18, p=.030)$ was also statistically significant, but in the opposite direction of what was predicted by the alternative hypothesis.

Women also rated the typical woman higher than men did on every category except Outgoing, where the mean score given by women was 3.58, compared to 3.59 mean score given by men. Four of the eight differences Emotionally Stable, Hardworking, Helpful and Intelligent - were significant. The difference in overall rating $(t$ (336) $=-4.30, p=.000$ ) was also statistically significant, but this time in the same direction predicted by the alternative hypothesis. Results are summarized in Table $5 \& 6$.

Table 5. T Scores comparing each Gender's view of the Typical Man

\begin{tabular}{|c|c|c|c|c|}
\hline \multicolumn{5}{|c|}{$M$ and $S D$} \\
\hline & $\begin{array}{r}\text { Male View } \\
\text { of Ty }\end{array}$ & $\begin{array}{l}\text { Female View } \\
\text { cal Man }\end{array}$ & $t(d f)$ & $\begin{array}{l}p \\
(1-\text { tailed })\end{array}$ \\
\hline Assertive & $3.86(.644)$ & $3.89(.741)$ & $-.502(299)$ & .308 \\
\hline Emotionally Stable & $3.71(.729)$ & $3.91(.859)$ & $-2.331(336)$ & $.010 *$ \\
\hline Hardworking & $3.70(.754)$ & $3.81(.772)$ & $-1.349(318)$ & .089 \\
\hline Helpful & $3.32(.798)$ & $3.30(.783)$ & $.126(336)$ & .450 \\
\hline Intelligent & $3.50(.691)$ & $3.61(.766)$ & $-1.344(336)$ & .090 \\
\hline Open to New Experiences & $3.49(.785)$ & $3.78(.879)$ & $-3.253(336)$ & $.000 *$ \\
\hline Outgoing & $3.45(.719)$ & $3.77(.776)$ & $-3.994(336)$ & $.000 *$ \\
\hline Reserved & $3.04(.775)$ & $2.81(.769)$ & $2.702(322)$ & $.004 *$ \\
\hline OVERALL & $3.51(.427)$ & $3.61(.457)$ & $-2.180(336)$ & $.015 *$ \\
\hline
\end{tabular}

$* \mathrm{p}$ value $<0.05$ and therefore considered significant

Table 6. T Scores comparing each Gender's view of the Typical Woman

\begin{tabular}{lcccc}
\hline & \multicolumn{2}{c}{$M$ and $S D$} & & \\
& Male View & Female View & & $p$ \\
& Of Typical Woman & & $(1$-tailed $)$ \\
\hline Assertive & $3.37(.822)$ & $3.44(.780)$ & $-.789(336)$ & .216 \\
Emotionally Stable & $2.75(.902)$ & $3.23(.658)$ & $-5.689(333)$ & $.000 *$ \\
Hardworking & $3.74(.688)$ & $4.04(.662)$ & $-4.092(326)$ & $.000 *$ \\
Helpful & $3.78(.783)$ & $4.02(.725)$ & $-2.908(330)$ & $.002 *$ \\
Intelligent & $3.70(.752)$ & $3.91(.615)$ & $-2.781(336)$ & $.003 *$ \\
Open to New Experiences & $3.44(.810)$ & $3.56(.689)$ & $-1.435(336)$ & .076 \\
Outgoing & $3.59(.773)$ & $3.58(.647)$ & $.221(336)$ & .413 \\
Reserved & $3.22(.810)$ & $3.35(.750)$ & $-1.536(336)$ & .063 \\
OVERALL & $3.45(.428)$ & $3.64(.381)$ & $-4.296(336)$ & .000 \\
\hline
\end{tabular}

$* \mathrm{p}$ value $<0.05$ and therefore considered significant

The ratings given by female respondents were significantly higher than those given by the male respondents for both the typical man and the typical woman. Therefore, while there were some significant differences, there is not sufficient support to either accept or reject Hypothesis Four.

\section{DISCUSSION AND CONCLUSION}

The purpose of this study was to explore for gender stereotyping among college students enrolled in business courses by examining beliefs and perceptions regarding the attributes that are important for success as a manager. Research has demonstrated the influence of gender stereotyping on such decisions as choice of academic major (Montgomery, 2004), choice of career (Konrad et al, 2000) and advancement (Agars, 2004). It was hoped that 
by considering how sexual stereotyping occurs among college students, its effect on such choices may be more recognized and then reduced. The data revealed very little difference in the way male and female students view themselves, but some significant differences in how they view themselves compared to how members of the opposite sex see them, and how they view members of the other sex.

A study by the American Association of University Women (Dey \& Hill, 2007) revealed that women earn, on average, $80 \%$ of what men earn in comparable jobs, even one year after graduating from college. Clearly the gender gap in pay still exists, beginning at the very early stages of people's career, when differences in amount of experience and family responsibilities are not yet significant. For that reason, this research has relevance for both educators and business managers.

Lai and Bond (1997) performed a study similar to this one, using the SAPPS instrument to measure self perception and gender stereotypes among Hong Kong students. In their conclusion, they suggested that future research should have each respondent "evaluate him-or herself, a typical person of his or her in-group, and a typical person of his or her out-group on multidimensional scales like SAPPS" (p. 32). This study has taken exactly that approach, to be able to measure not just self-ratings but also to provide an idea of how these students perceive the typical members of their own as well as the opposite sex.

\section{Summary And Discussion Of Results}

Male and female respondents mostly agreed on the importance of each of the attributes in terms of being a successful manager. They both ranked Hardworking at the top of the list, and Reserved at the bottom. Most of the other categories were no more than one rank apart in the male and the female lists. The only exception was "Assertive," which males ranked second and females ranked fourth. Interestingly, both men and women also saw men as more assertive than women. Men scored Assertiveness and Extroversion higher than women did. Women gave higher scores than men did on the other six categories.

\section{Results Of Hypothesis Testing}

Hypothesis 1 was supported: Undergraduate students (250 out of 338, or $74 \%$ ) gave themselves a higher rating than they gave the typical member of their own gender.

This is not surprising, as research has shown that most of us see ourselves as "above-average" in categories ranging from investment knowledge (Nofsinger, 2005) to driving ability (Robbins \& Judge, 2007). Even here, though, some gender difference begins to emerge. Men scored themselves much higher than the typical male, compared to how women scored themselves compared to the typical female. The t-statistic for men was $9.95(p<.01)$, while for women it was 6.2( $p<.001)$. Both these values were significant, but the men's was much stronger. Men have often been found to display more self confidence than women (Schein (1973), Ridgeway (2001)). The data in this study support those findings, with men seeing themselves as well above the crowd of their same-gender peers, much more so than women. This pattern was repeated, but more so, in the testing for Hypothesis 2, which was also supported. Undergraduate students in business classes will rate themselves higher than they rate the typical member of the opposite gender when ranking specific positive personality characteristics associated with successful managers. Here the t-value difference between men's view of themselves and their views of women was 14.21 $(p<.001)$, more than double the $6.13 \mathrm{t}$-value ( $\mathrm{p}<.001)$ when comparing women's views of themselves to their views of men. As was the case in Schein's more recent research (Schein \& Mueller, 1992), there is a bias in both groups for their own gender, but a much stronger one in men than in women, when it comes to traits of successful managers.

Hypothesis 3 was supported in its null form: As a group, male students rated themselves no differently than female students rated themselves. This finding was different from studies of Hong Kong students (Yim \& Bond, 2002) as well as some of Schein's earlier work (for example, Schein, 1975), which showed significantly higher selfscores among men than among women. This might indicate cultural difference, or possibly a growing sense of selfesteem in American female students. 
Within the self-scores, there were only two attributes whose $t$ scores did show a significant difference between men and women. These were Emotional Stability, where men's self ratings were higher than women's ( $t=3.63, p=.000)$, and Helpfulness, where women's self ratings were higher than men's $(t=2.08, p=.039)$. To put it another way, women scored themselves lower in emotional stability than men scored themselves. This could indicate some acceptance by the women of the stereotype of lower emotional stability. In the same way, men's lower self scores for helpfulness might show some acceptance by them of the stereotype that men are not helpful.

Some of the richest comparisons were found in the data testing Hypothesis 4, which could neither be accepted nor rejected. The comparisons of students' self views with the views of members of the opposite sex yielded some of the most significant differences in all of the comparisons of means. The hypothesis was that if there were a difference, women would rate women higher than men rate women. And men would rate men higher than women rate men. The female view of women was indeed higher than the male view. But the female view of men was also higher than the male view. The women in this sample gave overall higher scores to everyone than the men did.

Taking the comparison at an individual level, however, the story is different. Women and men both rated the typical member of their own sex and the opposite sex much lower than they rated themselves. These differences are much greater than the differences between self scores and how they view their own gender. The strength of those differences is shown in Table 7.

Table 7. T Scores comparing Male and Female Students' views

\begin{tabular}{ccc}
\hline & $\begin{array}{c}\text { View of self compared to } \\
\text { view of own gender }\end{array}$ & $\begin{array}{c}\text { View of self compared to } \\
\text { view of opposite gender }\end{array}$ \\
\hline Male Respondents & $9.95(p<.01)$ & $11.24(p<.001)$ \\
Female Respondents & $6.20(p<.01)$ & $6.13(p<.001)$ \\
\hline
\end{tabular}

When viewed in this way, the data indicate that men have much wider disparity between their views of themselves and their views of others people. This is not simply due to higher self-scores among men, since the self scores of men and women were not significantly different from each other. It is because men rate others lower than women do when making these comparisons. In fact, the $t$-stat was significant $(t=3.35, p=.012)$ when comparing men's view of women and women's view of men. This could be one factor that leads many men to negotiate better outcomes in terms of salaries and jobs, which might be one explanation for pay differences between men and women both at hiring and throughout their careers (Robbins \& Judge, 2007). Gender stereotyping may also play a role. Babcock \& Laschever (2003) found that both men and women tend to view negotiating skills more positively when men demonstrate them than when women do. Their research showed that men are many times more likely than women to initiate negotiations to improve their pay or position. Bowles, Babcock \& Lai (2007) also found most women to be more comfortable and more successful negotiating with another woman than with a man.

\section{Limitations}

The two schools included in the sample are located in the same geographic region and draw from the same general student population. Therefore, the results of this study cannot necessarily be generalized beyond the populations of these two schools.

The survey instrument used has an advantage of brevity over some other instruments. But this brevity can also create disadvantages, since people may interpret one word descriptions differently. 


\section{Suggestions For Future Research}

Certain patterns emerged in the data which, though not tested for in these hypotheses, might be subjects for future research. For example, the self-scores of the students at the State University were significantly higher than those of the private college students. Studies including a larger sample of students from more schools would be desirable.

A longitudinal study tracking the attitudes of the same students throughout their undergraduate education, similar to Yim \& Bond's study of Hong Kong students' gender perceptions over four years (2002) might yield information as to how and whether those attitudes change during a student's education.

\section{CONCLUSION}

The results showed that both men and women displayed some gender stereotyping. The fact that so many respondents, both male and female, scored themselves so much higher than either the typical man or the typical woman, is one indication of this. Men and women also supported such common stereotypes as that of men being more assertive and emotionally stable than women, and of women being more helpful than men.

The individual self-ratings of both male and female respondents were consistently and significantly higher than those they gave to typical members of either their own or the opposite sex. Most respondents expressed a strong sense of their own capabilities compared to others, regardless of gender.

Companies want to hire, promote and retain qualified people. People want meaningful jobs and fair wages. Gender stereotypes are one factor standing in the way of both of these goals. Women have made advancements but are still paid significantly less than men in most if not all occupations. The more that can be done to make people aware of their biases and stereotypes, and the earlier this education occurs, the greater the likelihood of success. If this awareness can be heightened while people are still in college, it should carry into the workplace and ultimately into decisions around hiring, promotion, and pay.

Kevin Bosner is an Assistant Professor of Management at Medaille College, Buffalo, NY, teaching accounting, finance, management and leadership. Before he began his academic career in 2003, Bosner held senior financial and administrative management positions at several companies. Bosner holds an M.B.A. in finance \& accounting from RIT, and completed his Ph.D. in organization and management from Capella University in 2007. He is a member of the Institute of Management Accountants, the Financial Executives Institute, the Society of Human Resource Managers, and Golden Key International Honour Society. He is a Certified Management Accountant and is certified in Business Process Re-Engineering.

\section{REFERENCES}

1. Agars, M. D. (2004). Reconsidering the impact of gender stereotypes on the advancement of women in organizations. Psychology of Women Quarterly, 28, 103-110.

2. Babcock, L. \& Laschever, S. (2003). Women don't ask. NJ: Princeton University Press.

3. Barrick, M.R. \& Mount, M.K. (1991). The big five personality dimensions and job performance: A metaanalysis. Personnel Psychology, 44(1). 1 - 26.

4. $\quad$ Bem, S.L. (1993). The lenses of gender. New Haven, CT: Yale University Press.

5. Brenner, O. (1982). Relationships of education to sex, managerial status, and the managerial stereotype. Journal of Applied Psychology, 67, 330-383.

6. Brenner, O., Tomkiewicz, and Schein,(1989). The relationship between sex role stereotypes and requisite management characteristics revisited. Academy of Management Journal, 32(3), 662-669.

7. Brown, D. (2002). The role of work and cultural values in occupational choice, satisfaction, and success: a theoretical statement. Journal of Counseling and Development, 80, 48-56.

8. Dey, J.G \& Hill, C. (2007). Behind the pay gap. Washington, DC: American Association of University Women. 
9. Dubeck, P. and Dunn, D. (2006) (Eds.) Workplace/women's place: An anthology (pp.142-156) Los Angeles: Roxbury.

10. Dubno, P. (1985). Attitudes towards women executives: A longitudinal approach. Academy of Management Journal, 28(1), 235-239.

11. Finlay, B. (2003). Facing the stained glass ceiling: gender in a protestant seminary. XIV ed. Lanham, MD: University Press of America.

12. Hofstede, G. (1983). The cultural relativity of organizational practices and theories. Journal of International Business Studies, 14 (2). 75-89.

13. Jackson, L. A., Hodge, C. N., \& Ingram J. M. (1994). Gender and self-concept: a reexamination of stereotypic differences and the role of gender attitudes. Sex Roles, 30(9/10), 615-628.

14. Kasi, B. and Dugger, J.C. (2000). Gender equity in industrial technology: the challenge and recommendations. Journal of Industrial Psychology, 16 (4). 2-9.

15. Konrad, A,. Ritchie, J., Lieb, P. \& Corrigal, E. (2000). Sex differences and similarities in job attribute preferences: A meta-analysis. Psychological Bulletin, 126 (4). 593-641.

16. Kunkel, A., Dennis, M.R. \& Waters, E. (2003). Contemporary university students' ratings of characteristics of men, women and CEO's. Psychological Reports, 93 (3). 1197-1213.

17. Lai, M. \& Bond, M.H. (1997). Gender stereotypes and the self-concept in Hong Kong youth. Bulletin of the Hong Kong Psychological Society, 38/39. 17-36.

18. Montgomery, L.M. (2004). 'It's just what I like': explaining persistent patterns of gender stratification in the life choices of college students. International Journal of Qualitative Studies in Education, 17, 785-802.

19. Morrison, A. M., White, R.P. \& Van Velsor, E. (1987). Breaking the glass ceiling, Reading, M.A.: Addison-Wesley.

20. Nofsinger, J.R. (2005) The psychology of investing ( $2^{\text {nd }}$ ed.) Upper Saddle River, NJ. Pearson Prentice-Hall.

21. Norris, J. M., \& Wylie, A. M. (1995). Gender stereotyping of the managerial role among students in Canada and the United States. Group and Organization Management, 20(2), 167-182.

22. Ragins, B. R., Townsend, B., \& Mattis, M. M. (1998). Gender gap in the executive suite: CEO's and female executives report female executives report on breaking the glass ceiling. Academy of Management Executive, 12(1), 28-42.

23. Ridgeway, C.L. (2001) Gender, status, and leadership. Journal of Social Issues, 57(4). 637-655.

24. Robbins, S.P. \& Judge, T.A. (2007). Organizational behavior. Upper Saddle River, NJ. Pearson PrenticeHall.

25. Sargent, L. (1981). Women and revolution: A discussion of the unhappy marriage of Marxism and Feminism. Boston, MA: South End Press.

26. Schein, V. E. (1973). The relationship between sex role stereotypes and requisite management characteristics. Journal of Applied Psychology, 57, 95-100.

27. Schein, V. E. (1975). Relationships between sex role stereotypes and requisite management characteristics among female managers. Journal of Applied Psychology, 60, 340-344.

28. Schein, V., Jueller, R., \& Jacobson C. (1989). The relationship between sex role stereotypes and requisite management characteristics among college students. Sex Roles, 20, 103-110.

29. Schein, V. E. \& Mueller, R. (1992). Sex role stereotyping and requisite management characteristics: A cross cultural look. Journal of Organizational Behavior, 13(5). 439-447.

30. Tai, A-J.R. \& Sims, R.L. (2005).the perception of the glass ceiling in high technology companies. Journal of Leadership and Organizational Studies, 12 (1). 16-23.

31. United States Department of Labor Women's Bureau. (2006) Women in the labor force in 2005. Retrieved March 29, 2006 from http://www.dol.gov./wb/factsheets/Qf-laborforce-05.htm.

32. Williams, N. (2005). Pre-hire pregnancy screening in Mexico's Maquiladoras: Is it discrimination? Duke Journal of Gender Law and Policy. Retrieved November 4, 2006 from https://www.law.duke.edu/ shell/cite.pl?12+Duke+J.+Gender+L.+\&+Pol'y+131.

33. Yim, P.C. and Bond, M.H. (2002). Gender stereotyping of managers and the self-concept of business students across their undergraduate education. Women in Management Review, 17(8). 364-371.

34. Zakaria, $\mathrm{N}$ (2000). The effects of cross-cultural training on the acculturation process of the global workforce. International Journal of Manpower, 21(6). 492-510. 


\section{APPENDIX.}

\section{Student Skills Perception Survey}

Please look at the eight words or phrases in the first column of the table below.

In column $\mathrm{A}$, write a number from 1 to 5 next to each word or phrase based on how you would complete the following sentence: "This word (phrase) describes me:..."

$5=$ extremely well $\quad 4=$ very well $\quad 3=$ somewhat $2=$ poorly $1=$ not at all

Next, place a number in column B to complete the sentence "This word (phrase) describes the typical man..." (Again, $5=$ extremely well, $1=$ not at all)

Now, do the same in column C, completing the sentence "This word describes the typical woman... "(Again, 5 = extremely well, $1=$ not at all)

Finally, place a number in column D to complete the sentence "This word (phrase) describes the typical successful manager..." (Again, $5=$ extremely well, $1=$ not at all)

\begin{tabular}{|l|c|c|c|c|}
\hline & \multicolumn{1}{|c|}{ A } & B & C & D \\
\hline & $\begin{array}{c}\text { This word or } \\
\text { phrase describes } \\
\text { me... }\end{array}$ & $\begin{array}{c}\text { This word or } \\
\text { phrase describes a } \\
\text { typical man... }\end{array}$ & $\begin{array}{c}\text { This word or } \\
\text { phrase describes a } \\
\text { typical woman... }\end{array}$ & $\begin{array}{c}\text { This word or } \\
\text { phrase describes a } \\
\text { typical successful } \\
\text { manager... }\end{array}$ \\
\hline Open to New Experiences & & & & \\
\hline Emotionally Stable & & & & \\
\hline Outgoing & & & & \\
\hline Hardworking & & & & \\
\hline Intelligent & & & & \\
\hline Helpful & & & & \\
\hline Reserved & & & & \\
\hline Assertive & & & & \\
\hline
\end{tabular}

Gender (Please Circle) Male $\quad$ Female

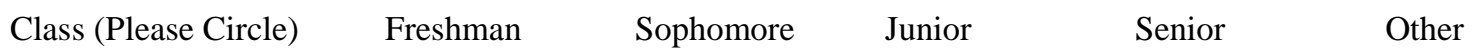

Academic Major

Age 